\title{
Üniversite Öğrencilerinin Dans Özyeterlikleri Üzerine Bir Çalıșma
}

\author{
Zeynel TURAN*
}

özet

Bu çalışma, farklı bölümlerde öğrenim gören ve halk dansları dersi seçen üniversite öğrencilerinin dans özyeterlik algılarını belirlemek amacıyla yapılmıştır. Çalışmaya, Celal Bayar üniversitesi’nin farklı bölümlerinde (Fakülte, Yüksekokul, Meslek Yüksekokulu) öğrenim gören ve Halk Dansları Dersi seçen 42'si kadın $(\% 72,4)$ ve 16’sı erkek $(\% 27,6)$ olmak üzere toplam 58 öğrenci katılmıştır. Çalışmaya katılan öğrencilerin tümü 2. sınıf öğrencilerinden oluşmaktadır. Araştırma süreci içerisinde bir ölçme aracı geliştirilmeye çalışılmış ve verilerin analizinde SPSS 20.0 programı kullanılmıştır. Geliştirilen ölçeğin faktör analizinden elde edilen KMO değeri .89 ve güvenirliği için elde edilen Cronbach Alpha katsayısı .94’tür. Yapılan analizler sonucunda halk dansları dersi seçen ve farklı bölümlerde öğrenim gören öğrencilerin, öğrenim gördükleri bölümler açısından dans özyeterlik algıları yüksek düzeyde $(\bar{X}=3,43-3,69)$ bulunmuş, gruplar arasında anlamlı bir fark olmadığı tespit edilmiştir $(p=, 397 ; p>0,05)$. Ayrıca, yapılan analizler sonucunda cinsiyetler arasında dans özyeterlik puanları bakımından ortalamalar arasında fark olmadığı $(\bar{x}=3,54-3,57)$ tespit edilmiştir. Alanyazın tarandığında, Türkiye'de dans özyeterlik ile ilgili yapılmış çalışmaların diğer alanlarda yapılan özyeterlik çalışmaları karşısında yok denecek kadar az durumda olmasının bu çalışmayı değerli kıldığı düşünülmektedir.

Anahtar Kelimeler: Ölçek Geliştirme, Dans Özyeterlik, Halk Oyunları, Halk Dansları.

\section{A Study on the Dance Self-Efficacy of University Students}

Abstract

The purpose of this paper is to characterize the perception of dance self-efficacy of undergraduate students from different departments who take folk dances as a selective course. The study is formed with the contribution of 58 students, comprising 42 women (\% 72,4) and 16 men (\%27,6) taking folk dances as a selective course in the spring semester of the 2013-2014 academic year in various departments (faculty and vocational school) of Celal Bayar University. The research consists of sophomores, 11 of which from Vocational Health School, 27 of which from Salihli Vocational School, and are 20 of which from the Faculty of Economics and Administrative Sciences. The research develops a certain instrument of assessment together with the use of SPSS 20.0 Programme for data analysis. The KMO value of the developed scale obtained from factor analysis is .89, and Cronbach Alpha ratio obtained for its reliability is .94. Results of analyses show that perception of dance self efficacy of undergraduate students from different departments who take folk dances as a selective course is appeared as high level $(\bar{x}=3,43-3,69)$ in terms of their departments in which they study, and that there is no considerable difference among groups. In addition, research analyses show that there is no difference between sexes $(\bar{x}=3,54-3,57)$ in terms of dance self efficacy scores. Considering that the number of self efficacy studies regarding dance in Turkey is very fewly compared to those in other areas as accessible literature shows, it is valuable to make research in this subject. Accordingly, this paper aims to develop a self efficacy scale specific to the area tested on undergraduate folk dance students.

Keywords: Kültürel Sermaye, Kültür Aracıları, Aracı Kültürel Sermaye, Mısırlı Ahmet, Darbuka. 


\section{Giriş}

İnsanın oluşumuyla ilk ortaya çıkan sanatsal değerler, 'müzik' ve 'dans’tır (Koçkar, 1990: 328). İlkel danslar genellikle aynı cinsiyetten olan ve beden etkileşiminin olmadığı şekilde yapılmış, grup içinde yer alarak diğer grup elemanlarıla kurulan sosyal ilişkiyle ve ortak amaç doğrultusunda canlanan grup dinamiği, bireylerin haz almalarını sağlamıştır. Bunun sonucunda öz saygılarının artması, bazı psikolojik ve sosyal problemlerin önlenmesine veya azaltılmasına yardımcı olmuştur (Özdemir 2007: 21).

Oyun, her türlü kültürden öncedir. Dahası kültürü yaratan tek öğedir. Din, dil, iş mitos ve ritüeller oyundan çıkmıştır. Her oyunun bir başlangıcı ve sonucu olduğu gibi mutlak bir amaca yöneliktir. Ayrıca tekrar edilir olması geleneksel bir biçim oluşturur (Barın, 1999: 3). Çağlar boyunca bilinen her kültürün önemli bir parçası olarak var olan dans, ortaya çıktığı kültürün ve toplumun sözsüz bir ifade aracı olarak iletişimin farklı bir şekli olmuştur (Board of Student 2003: 16) ve farklı kültürlerde insanlara, farklı şeyler ifade eder (McGreevy vd., 2005: 16). Kimi bölgelerde dans, toplum hayatında çok önemli bir yer tutar ve en güçlü sosyal dinamiklerden birisidir (Turan 2001).

Geçmişi 1300'lü yıllara dayanan dans kelimesinin kökünün Eski Fransızca'daki 'danse, dancier' olduğu düşünülmektedir (Kurtişoğlu ve Altuğ, 2009). Dans kelimesi, Almanca (Tanz); Fransızca (Danse); İngilizce (Dance) gibi dillerde hemen hemen aynıdır (Eroğlu, 1995: 16). Kökü tam belli olmasa da bu kelime sanat ve toplumlar üzerine Fransız kültürünün etkisinin gücüyle, İspanya'dan Rusya'ya oldukça geniş bir alana yayılmıştır (Kurtişoğlu ve Altuğ, 2009).

Dans nedir? sorusuna yanıt vermeye çalışan çok sayıda sanatçı ve bilim adamı, dansın önemini niteliğini ve kapsamını açıklayan, kendi bakış açıları çerçevesinde sayısız tanımlar geliştirmişlerdir. Hakkında birçok tanımlama yapılmış olan dans, Örnek'e göre (1973: 92) "kişinin, tinsel durumunu birtakım gövdesel devinimlerle açığa vurmasıdır”. Kassing ve Jay’e göre (2003: 4), “Dans, insan vücudunun zaman ve mekânda, enerji ve çabayla, vücudu yoluyla yaptığı ritmik hareketlerdir. Aynı zamanda bir dansçının, bir dansı, fiziksel, zihinsel ve ruhsal katkısıyla, sanat eseri olarak icra etmesidir". Nutku'ya göre ise (1983: 374), “müzik tartımına ve hızına uyularak yapılan, duygusal değer taşıyan düzenli ve uyumlu gövde devinimleridir".

Dans, sözlü kültürden de önce insanın ilkel tepkilerinin toplumsal bağlamda kendini ortaya koyduğu ilk olgulardan biridir (Barın, 1999: 1). Aktaş’a göre (1999: 4), “dans, insanın kendi duygu ve düşüncelerini anlatabilmesi ve toplumla bir iletişim kurabilmesi için anlam içeren hareketler topluluğunun, meydana getirdiği estetik ve ritmik özelliğe sahip bir yaratıcılığın sonucu olan fiziksel ve duygusal davranıştır”. Hanna, (1999) dansı, “insanlığı, sosyal ve davranışsal bilimi, sanat bilgisini, içine alacak bir şekilde düşünmek faydalı olacaktır” şeklinde açıklamıştır.

Dans, insan vücudunun uzayda, zaman içinde, enerji harcanarak gerçekleştirdiği ve tüm bu elementlerin birbirleriyle olan ilişkilerinden ortaya çıkan bir olgudur. Bu beş element (Beden, Uzay, Zaman, Enerji, İlişki), tüm dans formlarında öğrenme ve öğretme için temel olan unsurlardır. Bu unsurlar olmadan hareket edilemez (Franklin 1996: 4). Dansın elementleri, zaman, alan (mekân), uzay, enerji ve beden farkındalığıdır. Ayrıca dansçılar, nesneler ile ilgilidir. Bu beş temel dans öğesi bütün dans öğretiminin temelleridir ve dans eğitim programının temelini oluştururlar (McCutchen 2006: 129). Dansın unsurları dans çalışmasının merkezidir. Dans eden kişi zaman ve mekânda bu dinamikleri her zaman kullanır. Bunlar, duyguları ve fikirleri iletirken kullanılan araçlardır (Board of Studies 2003, 16).

Dans, yukarıdaki tüm ifadeler ve tanımlamalara ilave olarak, kişisel öz anlatımı, kültürel, inançsal ve estetik gibi anlamlı öğeleri de içeren bir davranış olarak meydana gelmektedir denebilir. Tüm bu tanımlardan yola çıkarak genel bir tanıma ulaşmak için diyebiliriz ki dans, bireyin duygu ve düşüncelerini yetkin bir biçimde dile getirip, toplumla iletişim kurabilmesini kolaylaştıran, çoğunlukla kültürün etkilediği, estetik ve sanatsal değerlerin ön planda olduğu, sözsüz, fiziksel, duygusal ve sembolik bir ritüeli olan, ritmik özelliğe sahip insan davranışıdır.

Dans birden bire ortaya çıkmış bir unsur değildir. Onu besleyen en önemli etken kültürdür. Dans kültürle 
şekillenir ama aynı zamanda şekillendiği kültürün taşıyıcısıdır. Kuşaktan kuşağa aktardığı iletilerle kültürün devamlılığına katkı sağlar (Yanık 2010: 154). Bu açıdan bakıldığında, halk dansları da insana kendini, kendi kültürünü, yaşadıklarını anlatan en etkili ve estetik yollardan biridir. Türk Halk Dansları da bir yönüyle dansın evrimsel sürecini yansıtmaktadır. Halk dansları da kültüre özgü ritüelleri, yaşantıları ifade etmenin en iyi yollarından biridir (Bozkurt, 2010). Kaepper’e göre (2003) dans, sosyal ve dinsel temaları taşıyan, kutlama, eğlence ve dinsel törenlerin anlamını içeren kültürel anlayışın sembolüdür.

Ekici'ye göre (2007: 8-10),

Halk, belli bir gelenek içinde oluşmuş yaratma sayesinde birbirine bağlanan, bir ürünü kendisine ait kabul eden bireylerden oluşan topluluktur. Metni, yapısı ve dokusu, oluşturulduğu şartlar ve çevre itibariyle kendine has sanat değeri olan bir yaratmaya sahip olduğunu iddia eden herhangi bir topluluk halk kavramı ile ifade edilebilir. Buna göre "Halk" kavramı, başlangıçtan itibaren oluşturulan ve içeriği veya kalıbı sürekli yenilenip geliştirilen, gelenek, görenek, inanç ve anlayışını devam ettiren veya devam ettirmeye çalışan bütün grupları, yani milleti içine almaktadır.

Baykurt'a göre (1995: 15), "Halk dansları hem toplumsal, hem de ulusal kültür konuludur. Halk dansları belirli bir devrin ya da şahısların değil, toplumların uzun yüzyıllar boyunca devam etmiş toplumsal ürünleridir”. Öztürk’e göre ise (1990: 71), "Günümüzde izlediğimiz danslar, izleyenler, üretenler, dans edenler ne isim verirlerse versinler, birer sanatsal üretimdir; bedenin gündelik dilinin dışına çıkarlar, dünyaya ve insan yaşantısına dair imge ve çağrışımlara yol açarlar”.

Çubukçu ve Girmen (2007)'e göre “Bireyin ulaşmak istediği hedefleri belirlemesinde öz yeterlik inançları etkili olmaktadır. Öz yeterlik inancı, bireylerin olası durumlarla başa çıkabilmek için gerekli olan eylemleri ne kadar iyi yapabileceklerine ilişkin bireysel yargılarılla ilgilidir. Bireylerin kendi kapasitelerine olan inançları, onların salip oldukları bilgi ve becerilerle neleri yapabileceklerine göre şekillenmektedir". Güvenç (2010)'e göre ise, "Özyeterlik algısı "yapabilirim" olarak ifade edilebilecek yeterlilik ve kapasitelerle ilgilidir. Özyeterlik algısının ise "bunu yapabilirim" şeklinde, bireyin alana özel yargılarını içerdiği söylenebilir”.

Öz yeterlik, Bandura'nın (1977) davranış üzerinde etkili olduğunu düşündüğü ve Sosyal Öğrenme Kuramında vurgulanan önemli kavramlardan biridir. Bandura (1986), "Bireyin belli bir performansı göstermek için gerekli etkinlikleri organize edip başarılı olarak yapma kapasitesine ilişkin kendi inancına öz yeterlik denir” (Akt. Özgen ve Bindak 2011: 1073-89).

Yıldırım ve İlhan'a göre (2010),

Özyeterlik yetenekli olmaya değil, kişinin kendi kaynaklarına güvenmesine karşılık gelen bir kavramdır. Bir durumla baş etmede yeterli becerileri olan, ancak özyeterliliği düşük olan kişi, söz konusu becerilerini harekete geçiremeyecektir. Özyeterlik kavramı, bir eylemin planlanması, gerekli becerilerin farkında olunması ve örgütlenmesi, zorluklarla birlikte elde edilecek kazançların gözden geçirilmesi sonucunda oluşan güdülenme düzeyi gibi öğeleri içerir.

Özyeterlik kavramını literatüre kazandıran Bandura (1994), "kişinin belli bir performansı göstermek için gerekli etkinlikleri organize edip, başarılı olarak yapma kapasitesi hakkında kendine ilişkin yargısı" olarak tanımlamaktadır. Bu doğrultuda bir kişi bir işin gerektirdiği becerilere sahip olmasına rağmen, o işi yapabileceğine dair düşük düzeyde yeterlik inancına sahip ise, onun o işte başarısız olabileceği dikkati çekmektedir (akt. İkiz ve Yörük, 2013). Öz-yeterlilik, bireyin gelecekte karşılaşabileceği güç durumların üstesinden gelmede ne derecede başarılı olabileceğine ilişkin kendi hakkındaki yargısı, inancıdır (Senemoğlu, 2009).

Yapılan araştırma sonucunda, ülkemizde kullanılan öz-yeterlik ölçekleri genellikle akademik başarı, fizikselduygusal davranışlar ve algılar konusundaki alanlara odaklanmış durumda olduğu görülmektedir. ${ }^{1}$

Erişilebildiği ölçüde alanyazın tarandığında, Türkiye'de dans özyeterlik ile ilgili yapılmış çalışmaların (Tokinan, 2008; Tokinan ve Bilen, 2010; Daşdan, 2013), 
diğer alanlarda yapılan özyeterlik çalışmaları karşısında yok denecek kadar az durumda olması bu konuda çalışmayı değer kılmaktadır.

$\mathrm{Bu}$ araştırmanın amacı, üniversitelerin farklı bölümlerinde öğrenim gören halk dansları dersi seçen öğrencilerin, dans özyeterlik algılarını belirlemektir. Bu doğrultuda, alana özel, özyeterlik algısı ölçeği geliştirilmesi amaçlanmış ve üniversiteli halk dansçılar üzerinde sınanmıştır.

\section{Yöntem}

\section{Çalışma grubu}

Bu çalışma 2013-2014 Eğitim Öğretim Yılı Bahar Dönemi'nde Celal Bayar üniversitesinin farklı bölümlerinde (Fakülte, Yüksekokul, Meslek Yüksekokulu) öğrenim gören ve ortak zorunlu dersler kapsamında, Halk Dansları Dersi seçen 2. sınıf öğrencileri ile uygulanmıştır. Uygulama 42'si kadın (\%72,4), 16'sı erkek (\%27,6) olmak üzere toplam 58 öğrenci ile yürütülmüştür.

Uygulamaya katılan öğrencilere ilişkin bilgiler aşağıdaki tablolarda (Tablo 1-2-3) gösterilmiştir.

\begin{tabular}{lll}
\hline Bölümler & N & $\%$ \\
\hline Sağ̆tk Y.O & 11 & 19,0 \\
Salihli M.Y.O & $\mathbf{2 0}$ & 34,5 \\
Iktisadi ve Idari Bil.Fak. & 27 & 46,6 \\
Toplam & $\mathbf{5 8}$ & $\mathbf{1 0 0}$ \\
\hline
\end{tabular}

Tablo 1: Uygulamaya katılan öğrencilerin öğrenim gördükleri bölümler

Tablo 1 incelendiğinde, Sağlık Y.Okulundan 11 öğrenci (\% 19,0), Salihli M.Y Okulundan 20 öğrenci $(34,5)$, İktisadi ve İdari Bilimler Fakültesinden 27 öğrenci $(\% 46,6)$ öğrenci uygulamaya katıldığı görülmektedir. Ayrıca, uygulamaya katılan öğrencilerin tümü 2. Sınıfta öğrenim görmektedir.

\begin{tabular}{lllll}
\hline & N & Min. & Max. & Ort. \\
\hline Yas & 58 & 17,00 & 22,00 & 19,2586
\end{tabular}

Tablo 2: Uygulamaya katılan öğrencilerin yaş aralıkları
Tablo 2 incelendiğinde, uygulamaya katılan öğrencilerin yaş aralıklarının minimum 17 ile maksimum 22 arasında değiştiği ve uygulamaya katılan öğrencilerin yaş ortalamasının 19,25 olduğu görülmektedir.

\begin{tabular}{ccc}
\hline & N & $\%$ \\
\hline Kadın & 42 & 72,4 \\
Erkek & 16 & 27,6 \\
\hline
\end{tabular}

Tablo 3: Uygulamaya katılan öğrencilerin cinsiyetleri

Tablo 3 incelendiğinde, uygulamaya katılan öğrencilerin 42'si kadın $(\% 72,4), 16$ 'sının erkek $(27,6)$ olduğu görülmektedir.

\section{Ölçeğin Geliştirilme Aşaması}

Araştırmacı tarafından, halk dansları dersi seçen üniversiteli öğrencilerin dans özyeterlik algılarını ölçmeye yönelik ölçek taslağı oluşturulmadan önce, ilgili literatür gözden geçirilerek, alanda bu konu ile ilgili yapılmış çalışmalarla, (Tokinan, 2008; Yoncalık, 2007; Acuner, 2012) karşılaştırılmış ve çalışma kapsamına alınmış 7 madde (1 madde Yoncalık, 2007, 6 madde Tokinan 2008) dışında kalan maddelerin ve çalışma konusunun diğer çalışmalar ile uyumlu olmadığı tespit edilmiştir. "Yargısal ölçmelerde, herkesçe üzerinde anlaşılmış gözlenebilir ölçüt ve standartlar yoktur. Bunlar, tümüyle, dolaylı ölçmeler olup göreli sonuçlar verirler” (Karasar, 2008: 139). Ölçmede, ölçme konusu olan şey, bir özelliktir. Belli bir özelliğe sahip olup olmama objeden objeye, kişiden kişiye, durumdan duruma ve ayn objeye veya birey için zamandan zamana değişebilmektedir" (Tavşancıl, 2014: $3)$.

Halk dansları dersi seçen öğrencilerin dans özyeterlik algılarını ölçmeye yönelik hazırlanan taslak ölçek 44 sorudan oluşmuştur. Uygulamaya konmadan önce hazırlanmış olan taslak ölçek; halk dansları, aerobik jimnastik ve sosyal latin dansları alanında öğretim görevlileri ve eğitmenlerinden oluşan uzman görüşlerine sunularak kapsam geçerliği sınanmıştır. "İçerik geçerliğini belirlemek isteyen bir araştırmacının ilk işi, hazırladığ test, anket ya da benzeri ölçü aracını ve amaçlarını bir "uzman gruba” inceletmek olmalıdır" (Karasar, 2008: 152). 
Taslak maddeler ön elemeye alındıktan sonra, uzmanlar tarafından bazı maddelerin çıkarılmasına karar verilmiştir. "Likert ölçeği hazırlanırken ölçmek isteneni ölçen ifadeler belirlenir ve yazılır. Ön inceleme ile soru ve seçenekler test edilir. Düzeltmeler yapılır ve soru uygulamaya hazır hale getirilir” (Erdoğan, 2007: 222).

Ölçek taslağı için 5’li Likert tipi ölçek kullanılması benimsenmiştir. Dereceleme biçimi "Oldukça Çok (5), Çok (4), Orta (3), Az (2), Hiç (1)" şeklindedir. "Ölçekteki orta noktadaki "kararsızlık" ile hiç cevap vermemeye yol açabilecek "fikrim yok" tepkileri birbirinden farklıdır. Buradaki orta nokta pozitif ve negatif yönde tepki tercihlerinde hissedilen güçlüğü ya da gerçek anlamda "orta yol" tercihini temsil etmektedir" (Karasar, 2005: 142). Oluşturulan taslak form, öğrencilerin serbest zaman dilimleri içerisinde ve gönüllü olarak katılımları sağlanarak doldurulmuştur.

\section{Çalışma Grubu Ders Planı}

Araştırmaya katılan gruplara 12 hafta boyunca, haftada 1 gün, 2 ders saati Halk Dansları türlerinden farklı ritmik özelliklere ve dans karakterlerine sahip yöre adımları öğretilmiştir. Başta müzik ve ritim alıştırmaları olmak üzere, öğretilecek hareketlere ilişkin form bilgisi, hareket analizi gibi öğretim tekniklerinin yanı sıra, Anlatma, Gösterip yaptırma gibi öğretim yöntemleri esaslarına dayalı oluşturulmuş karma ders programı uygulanmıştır.

Seçilen yöre dansları ritmik özellikleri (zamanı) bakımından 9/4'lük, 9/8'lik, 6/4'lük, 7/8'liktir. Hızları (dinamik) bakımından hızlı ve yavaş olacak şekilde oyunlar seçilmiştir. Alan kullanımı bakımından çember düzeni ve düz çizgi halinde icra edilen aynı zamanda farklı yönlerde (öne-geriye / sağa-sola) hareket edilebilecek halk dansları tercih edilmiştir. Bunlar; Zeybek (harmandalı), Karşılama (sülmanaga), Halay (Galuç), Horon (düz horon- Karadeniz 10'lusu)'dur.

\section{Verilerin Analizi}

Üniversitelerin farklı bölümlerinde öğrenim gören ve halk dansları dersini seçen öğrencilerin, dans özyeterlik algılarını belirlemeye yönelik hazırlanan taslak ölçeğe ait verilerin analizi için SPSS20 programı kullanılmıştır.
Ölçekte yer alacak maddelerin faktör yüklerini belirlemek amacıyla Kaiser-Meyer-Olkin (KMO) ve Barlett Sphericity testi kullanılmıştır. "Örneklemden elde edilen verilerin yeterliğinin saptanması için Kaiser-Meyer-Olkin (KMO)testi yapılmaktadır” (Tavşancıl, 2014: 50). Ölçeğin güvenirliği için, Cronbach Alpha ve Spearman Brown katsayıları hesaplanmıştır.

\section{Bulgular}

\section{Faktör Analizi}

Uzman değerlendirmesi ve taslaktan çıkarılan maddelerden sonra elde kalan sorular ile 27 maddelik deneme formu oluşturulmuş ve kalan maddeler ölçekte ilk sıralandığı biçimde, madde numaraları değiştirilmeden derse katılan öğrencilere uygulatılmıştır. Bu maddelerin 4'ü olumsuz, 23'ü olumlu sorudan oluşmaktadır. "Ölçekteki maddelerin ölçeğe katkısını incelemek için yapılan işlemlere madde analizi adı verilir. Bu amaçla, geliştirilen ölçek ilgili evrenin bir alt örneklemine uygulanır" (Alpar, 2006: 331). Ölçeğin oluşturulmasından sonra elde kalan 27 maddelik taslak ölçeğin ilk uygulamasında faktör korelasyonu 0.40 olarak benimsenmiştir. "Araştırmacılar, Korelasyonlar için manidar bir ölçüte karar verirler ve bu genellikle 0.30 veya daha yüksek bir değer olur" (Tavşancıl, 2014: 50).

Yapılan ilk analiz sonuçlarına göre KMO (KaiserMeyer-Olkin Measure of Sampling Adequacy) değeri 0,791; Barlett Testi de anlamlı $(1368,132 ; p<0,001)$ bulunmuştur. "Faktör analizinde evrendeki dağılımın normal olması gerekmektedir. Verilerin çok değişkenli normal dağılımdan geldiği Bartlett testi ile test edilmektedir. Test sonucu ne kadar yüksek ise, manidar olma olasılı̆̆ı o kadar yüksektir” (Tavşancıl, 2014:51). Yapılan ilk incelemenin sonuçları aşağıdaki tabloda (tablo 4) gösterilmiştir.

\begin{tabular}{lll}
\hline Kaiser-Meyer-Olkin Ómeklem Uyum Ölçūsũ & & 0,812 \\
Barlett Küresellik Testi & $\mathrm{X}^{2}$ & 1108,184 \\
& df & 325 \\
& $\mathrm{P}$ & 0,000 \\
\hline
\end{tabular}

Tablo 4: KMO ve Barlett testi sonuçları

Tutum ölçeğinde bulunan 27 maddeye ilişkin Varimax rotasyon yöntemi kullanılarak yapılan ilk temel bileşenler 
faktör analizi işlemi sonucunda özdeğerleri 1'den büyük dört faktör elde edilmiştir. Bu dört faktör, toplam varyansın \%69,243'ünü açıkladığı gözlenmiştir. Faktör yük değerlerini belirmek amacıyla yapılan Kaiser-Meyer-Olkin (KMO) testi sonuçlarına ait bilgiler tablo 5’te verilmiştir.

\begin{tabular}{|c|c|c|c|c|}
\hline Maddeler & 1 & 2 & 3 & 4 \\
\hline$\overline{\mathrm{s} 1}$ &, 832 & & & \\
\hline s16 &, 830 & & & \\
\hline $\mathrm{s} 43$ &, 810 & & & \\
\hline $\mathrm{s} 38$ &, 808 & & & \\
\hline s44 &, 769 & & & \\
\hline s2 &, 749 & & & \\
\hline s22 &, 746 & & & \\
\hline s25 &, 744 & & & \\
\hline s7 &, 742 & & & \\
\hline $\mathrm{s} 20$ &, 737 & & & \\
\hline $\mathrm{s} 36$ &, 719 & & & \\
\hline s37 &, 707 & & & \\
\hline s6 &, 703 & & & \\
\hline $\mathrm{s} 40$ & 689 & & & \\
\hline s3 &,- 684 & & ,444 & \\
\hline s31 & 672 & & & \\
\hline $\mathrm{s} 33$ &, 616 &,- 418 & & \\
\hline s35 &, 508 & & &,- 502 \\
\hline s34 &, 485 & & &,- 463 \\
\hline $\mathrm{s} 13$ & &, 700 & & \\
\hline s21 & .455 &, 578 & & \\
\hline $\mathrm{s} 23$ & ,508 & ,546 & & \\
\hline s28 & &,- 472 &, 541 & \\
\hline s27 & &, 501 &,- 521 & \\
\hline s41 &, 446 & &,- 450 & \\
\hline s14 &,- 544 & & &, 562 \\
\hline s1 &, 832 & & & \\
\hline
\end{tabular}

Yapılan temel bileşenler faktör analizi işlemi sonucunda, 13. 28. ve 27. maddelerin faktör yük değerlerinin 0.40 'tan küçük olduğu tespit edilmiştir. Bir sonraki yapılacak analizlerde, ölçeğin yapısına uymayan ya da birden fazla faktöre yük veren maddeler ölçekten çıkarılmıştır. "Uygulamada az sayıda madde için faktör yük değeri 0.30’a kadar indirilebilir” (Karasar, 2005: 124). Ayrıca faktör yük değerleri 0,40 'ın üstünde olmasına rağmen Cronbach Alpha güvenirlik katsayısını düşüren 3. 14. 21. 23. 34. 35. ve 41. maddeler de yapılacak yeni teste tabi tutulmamışlardır. "Bir madde ölçekten çıkarıldığındaki alfa katsayısı, ölçeğin tümü için hesaplanan alfa katsayısına göre artış gösterirse, o maddenin "güvenirliği azaltan" bir madde olduğu söylenir ve bu maddenin ölçekten çıkartılması önerilir” (Alpar, 2006: 332).

Bu maddeler çıkarıldıktan sonra ölçeğin yapı geçerliği için tekrar faktör analizi yapılmıştır. Çıkarılan maddelerden sonra yapılan doğrulayıcı faktör sonuçları ve yeni faktör yük değerlerine ait bilgiler tablo 6'da verilmiştir.

Tablo 6'ya göre ölçekte kalan maddelerin faktör yük değerlerinin, 1 faktör üzerinde yoğunluk gösterdiği tespit edilmiştir. Bu işlemler sonucunda ölçeği oluşturan maddelerin 1. faktördeki yük değerleri 0,613 ile 0,871 arasında değiştiği gözlenmiştir. Birinci faktörde yer alan maddelerin toplam varyansın \% 56,923'ünü, açıklamaktadır.

\begin{tabular}{|c|c|c|}
\hline \multicolumn{2}{|c|}{ Ölçekte $\quad$ Kalan } & \multirow[b]{2}{*}{2} \\
\hline Maddeler & 1 & \\
\hline s1 & .871 & \\
\hline s16 & .840 & \\
\hline$s 43$ & .822 & \\
\hline $\mathrm{s} 38$ &, 796 & \\
\hline s44 & 769 & \\
\hline $\mathbf{s} 25$ &, 768 & \\
\hline s7 & .756 & \\
\hline$s 2$ & .754 & \\
\hline $\mathrm{s} 20$ &, 747 &,- 424 \\
\hline $\mathrm{s} 22$ &, 746 &,- 469 \\
\hline s6 &, 746 & \\
\hline $\mathrm{s} 36$ &, 735 & \\
\hline$s 40$ & 707 & .521 \\
\hline s37 & 686 & \\
\hline $\mathbf{s} 31$ & .673 & \\
\hline $\mathbf{s 3 3}$ &, 613 & \\
\hline
\end{tabular}

Tablo 6: Ölçekten çıkarılan maddelerden sonra ölçekte kalan maddelerin döndürülmüş faktör yük değerleri 
Ölçeğin oluşturulmasındaki madde seçimine esas alınan örneklemin yeterliliğini belirlemek amacıyla, taslak ölçeğin analizlerinde Kaiser-Meyer Olkin (KMO) katsayısı ve Barlett Sphericity testi uygulanmıştır. "Verilerin açımlayıcı faktör analizine uygun olup olmadığına dikkat etmek gerekmektedir. Bunun için öncelikle örneklem büyüklüğünün yeterli olup olmadığı araştırılmalıdır. Örneklemin büyüklüğünü test etmek için Kaiser-MeyerOlkin (KMO) katsayısı hesaplanmaktadır” (Tavşancıl, 2005; Büyüköztürk, 2010: 126).

\begin{tabular}{lll}
\hline Kaiser-Meyer-Olkin Örneklem Yeterliliği Ölçümü &, 892 \\
& Ki Kare Değeri & 702,835 \\
Bartlett's Küresellik Test Değeri & df & 120 \\
& Sig. &, 000 \\
\hline
\end{tabular}

Tablo 7: Ölçekte kalan 12 maddeye uygulanan faktör analizi sonucunda elde edilen KMO değerine ait bilgiler

“Faktörleştirilebilirlik (faktorability) için KMO'nun .60'dan yüksek çıkması beklenir” (Büyüköztürk, 2010:126). Tablo 7'de çalışma kapsamına alınan örneklemin yeterliliğini belirlemek amacıyla yapılan analiz sonuçlarına göre KMO değeri 0,892 olarak tespit edilmiş ve bu değer örneklem büyüklüğünün faktör analizi için 'çok iyi' olduğu sonucuna varılmıştır. "Kaiser, bulunan değerin 1'e yaklaştıkça mükemmel, 0,50'nin altında ise kabul edilemez $(0,90$ 'larda mükemmel, 0,80 'lerde çok iyi, 0,70 'lerde ve 0,60 'larda vasat, 0,50 'lerde kötü) olduğunu belirtmektedir" (Tavşancıl 2005). Barlett küresellik testi sonuçları ise ki-kare $\left(X^{2}(120)=702,835 ; p<.01\right)$ değerinin anlamlı olduğunu göstermektedir. Tüm bu bulgular, ölçeğin tatmin edici düzeyde yapı geçerliğine sahip olduğuna ilişkin kanıt olarak gösterilebilir.

Klasik test kuramına göre geliştirilen Likert tipi ölçeklerde madde seçmede genelde, Korelasyona ve $\% 27$ 'lik alt-üst grup ortalama farkına dayalı teknikler kullanılmıştır (Şahin ve Gülleroğlu 2013). Standart ölçek geliştirmede normal dağılan büyük gruplarda, madde istatistikleri geleneksel olarak \%27'sinın kuralına göre ayrılmış zıt gruplar üzerinde yapılmaktadır (Özgüven, 2014: 133).

Büyüköztürk’e göre (2010: 171), “Madde analizi kapsamında başvurulan bir başka yol, testin toplam puanlarına göre oluşturulan alt $\% 27$ ve üst\%27'lik grupların madde ortalama puanları arasındaki farkların ilişkisiz t-testi kullanılarak sınanmasıdır”. Ölçeğin iç tutarlığına kanıt sağlamak amacıyla yapılan, alt \%27 ve üst $\% 27$ 'lik grupların ölçeğe verilen puanların ortalamalarına ve madde ortalama puanlarına ait T-Testi sonuçları aşağıda sunulmuştur.

\begin{tabular}{|c|c|c|c|c|c|}
\hline Greplar & $N$ & $\overline{\boldsymbol{x}}$ & Std. & $t$ & p \\
\hline \multirow[t]{2}{*}{ att $\% 27$} & 15 & 2,3708 &, 62297 & 12,043 & \\
\hline & & & & & $0.000^{*}$ \\
\hline est\%27 & 15 & 4,4708 &, 26078 & .06733 & \\
\hline
\end{tabular}

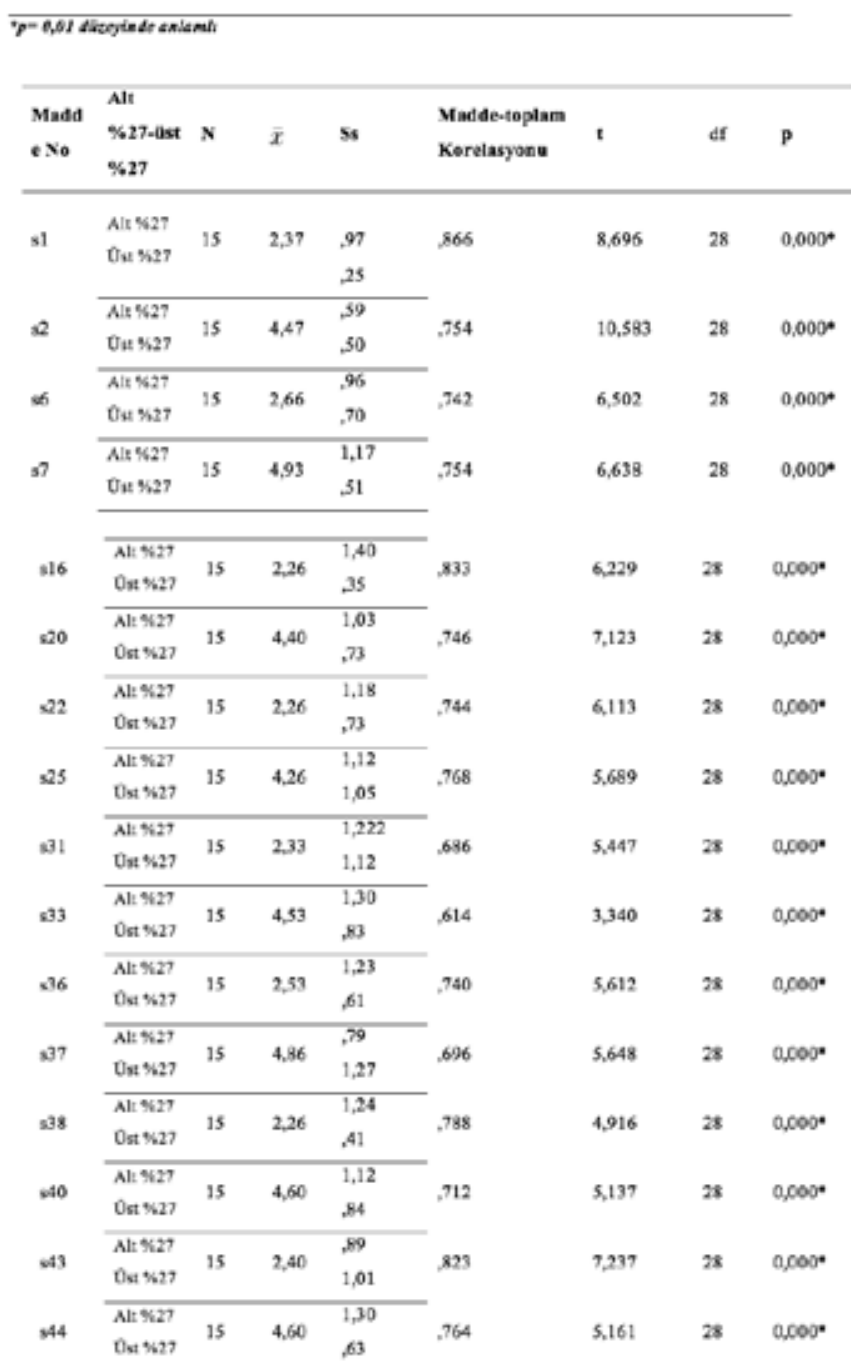

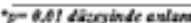

Tablo 8: Alt-Üst \%27’lik gruplara göre t-testi sonuçları

Tablo 8 incelendiğinde, ölçekte yer alan tüm maddeler için madde-toplam Korelasyonların .614 
ile .866 arasında değiştiği ve p-değerlerinin anlamlı $(p<0,01)$ olduğu görülmektedir. Bu sonuçlar, ölçekteki maddelerin geçerliklerinin yüksek olduğu, yöntemsel yeterlikler bakımından öğrencileri ayırt ettikleri ve aynı davranışı ölçmeye yönelik maddeler oldukları şeklinde yorumlanabilir.

Araştırma kapsamında kullanılması düşünülen Likert tipi ölçek hazırlanırken, soruların zorluk derecesi (Communalities, Extraction) .20 ile .80 arasında belirlenmiştir. "Genel bir eğilim olarak sorunun seçenek sayısı arttıkça soruların güçlük derecesi artar. Soruların güçlük derecesinin ortalarda, .40-.60 arasında alması istenir. Yaygın bir görüş olarak bir sorunun güçlük derecesi 0,15 'in altında (zor) ve 0.85 'in üstünde (kolay) olması nedeniyle testlerde kullanılmaz (Özgüven, 2014: 128). Aşağıdaki tabloda (9) soruların zorluk derecesi belirtilmiştir.

\begin{tabular}{|c|c|c|}
\hline $\begin{array}{l}\text { Madde } \\
\text { numaras }\end{array}$ & Başlangı̣ & Zorluk derecesi \\
\hline s1 & 1,000 & 759 \\
\hline$s 2$ & 1,000 & 608 \\
\hline s6 & 1,000 & .584 \\
\hline 87 & 1,000 &, 584 \\
\hline$s 16$ & 1,000 & 793 \\
\hline$s 20$ & 1,000 & 738 \\
\hline $\mathrm{s} 22$ & 1,000 & 777 \\
\hline $\mathrm{s} 2 \mathrm{~S}$ & 1,000 & 606 \\
\hline s31 & 1,000 & 481 \\
\hline $\mathrm{s} 33$ & 1,000 & 405 \\
\hline $\mathrm{s} 36$ & 1,000 & 664 \\
\hline $\mathbf{s 3 7}$ & 1,000 & 537 \\
\hline 838 & 1,000 & 634 \\
\hline$s 40$ & 1,000 & 771 \\
\hline s43 & 1,000 & 781 \\
\hline s44 & 1,000 & 608 \\
\hline
\end{tabular}

Tablo 9: ölçekteki soruların zorluk dereceleri

\section{Güvenirlik}

Yapılan analizler sonucunda 16 madde ile son hali verilen ölçeğin alt boyutlarına ve tamamına ilişkin güvenilirlik analizleri aşağıdaki tabloda (10) sunulmuştur.

\begin{tabular}{lllll}
\hline Madde Saysı & N & Cronbach Alpha & Spearman Brown & Guttman Split-Half \\
\hline 16 & 58 & .948 & .891 & .890
\end{tabular}

Tablo 10: Tutum ölçeği güvenirlik analizi sonuçları

Ölçeğin Cronbach Alpha güvenirlik katsayısı ise 0,948 olarak bulunmuştur. Fink ve Kosecoff, (1985), “Bir tutum ölçeğinin güvenilir olduğunu söyleyebilmek için, hesaplanan Korelasyon katsayısının en az 0,70 olması gerekmektedir" (Tavşancıl, 2014: 25'den alıntı).

Ölçeği oluşturan maddelere ilişsin ortalama, standart sapma, madde-toplam Korelasyonu ve madde silindiğinde güvenirlik katsayılarına ait sonuçlar aşağıdaki tabloda (tablo 11) sunulmuştur.

\begin{tabular}{lllll}
\hline Madde & $\bar{x}$ & Std & $\begin{array}{l}\text { Madde Toplam } \\
\text { Korelasyonu }\end{array}$ & $\begin{array}{l}\text { Madde } \\
\text { Silindiginde } \\
\text { Cronbach Alpha }\end{array}$ \\
\hline s1 & 4,01 & 1,06 &, 845 &, 942 \\
s2 & 3,41 & 1,09 &, 717 &, 944 \\
s6 & 3,50 & 1,09 &, 703 &, 945 \\
s7 & 3,68 & 1,18 &, 713 &, 944 \\
s16 & 3,86 & 1,17 &, 805 &, 942 \\
s20 & 3,39 & 1,21 &, 703 &, 945 \\
s22 & 3,56 & 1,15 &, 703 &, 945 \\
s25 & 3,50 & 1,24 &, 727 &, 944 \\
s31 & 3,31 & 1,32 &, 630 &, 947 \\
s33 & 3,86 &, 981 &, 567 &, 947 \\
s36 & 3,43 & 1,17 &, 698 &, 945 \\
s37 & 3,20 & 1,30 &, 642 &, 946 \\
s38 & 3,93 &, 970 &, 759 &, 944 \\
s40 & 3,27 & 1,08 &, 670 &, 945 \\
S43 & 3,25 &, 92 &, 790 &, 728 \\
S44 & 3,65 & 1,15 & &, 944 \\
\hline
\end{tabular}

Tablo11: Madde-Toplam test Korelasyon sonuçları

Tablo 11 incelendiğinde, madde-toplam test Korelasyonlarının 0,56 ile 0,84 arasında değiştiği ve maddelerin herhangi birinin ölçekten atıldığı takdirde güvenirlik katsayısını azaltmadığı görülmektedir. 
"Güvenirlik katsayısı birçok halde korelasyon katsayısı olarak ifade edilmektedir. Korelasyon, iki değişken arasındaki ilişkinin derecesi ve yönü hakkında bilgi vermekte, -1 ile +1 arasında değerler almaktadır. Korelasyonun pozitif sınırlar içinde ve oldukça yüksek olması arzu edilmektedir" (Özgüven, 2014: 103). Ölçekten elde edilen güvenirlik katsayısı (Cronbach Alpha) ,948 olarak bulunmuştur. Bu bulguya göre ölçeğin güvenirliğinin oldukça yüksek olduğu söylenebilir.

\section{Üniversiteli Halk Dansçıların Dans Özyeterlik Durumlarının Tespiti}

Araştırma kapsamında geliştirilen ölçeğin normal dağılıma uyup uymadığını anlayabilmek için Kolmogorov-Smirnov testi, varyansların homojenliği testi için ise Oneway Anova testleri uygulanmıştır.

\begin{tabular}{llll}
\hline Cinsiyet & \multicolumn{2}{l}{ Kolmogorov-Smirnov } \\
& İstatistik & df & $\mathrm{p}$ \\
\hline Kadın &, 259 & 42 &, $000^{*}$ \\
Erkek &, 398 & 16 &, $000^{*}$ \\
\hline
\end{tabular}

Tablo 12: Kolmogorov-Smirnov normallik dağılım testi

Araştırmaya katılan denek sayısının 50'den fazla olması nedeniyle normallik testi için Kolmogorov-Smirnov testi kullanılmıştır. Tablo 12 incelendiğinde, verilerin normal dağılıma uygun olmadığı tespit edilmiştir $(p<$ 0,05).

Aşağıdaki tabloda (tablo 13) farklı bölümlerde öğrenim gören halk oyuncuların dans özyeterlikleri ölçeğine verdikleri puanlar arasında ortalamaları bakımından farklılık olup olmadığı test edilmiştir.

\begin{tabular}{|c|c|c|c|c|c|}
\hline Bosamier & $\mathrm{N}$ & $\bar{x}$ & Std. & Levene Testi & $\mathbf{p}$ \\
\hline Saflek & 11 & 3,69 & 651 & \multirow{4}{*}{, 938} & \multirow{4}{*}{, 397} \\
\hline Salibli M.Y.O & 20 & 3,64 & .896 & & \\
\hline t.t.B.F & 27 & 3,43 & 933 & & \\
\hline Toplan & 58 & 3,55 & $\$ 867$ & & \\
\hline
\end{tabular}

Tablo 13: Oneway Anova testi sonuçları

Tablo 13 incelendiğinde grupların ölçeğe verdikleri ortalama puanlarına göre, farklı bölümlerde öğrenim gören halk oyuncuların dans özyeterliklerinin yüksek olduğu ( $\bar{x}$ =3,43-3,69), gruplar arasında anlamlı bir fark olmadığ tespit edilmiştir ( $p=, 397 ; p>0,05)$. Öğrenim gördükleri bölümler açısından öğrenci gruplarının aralarında fark olup olmadığını anlayabilmek için grupların ölçekten aldıkları ortalama puanları Anova testi ile sınanmıştır. Ayrıca varyansların eşitliğine göre Post Hoc testleri (Tukey ve LSD) sonuçları aşağıda gösterilmiştir (tablo 14-15).

\begin{tabular}{lccccc}
\hline \multicolumn{1}{c}{ Ortalama } & Karcler Teplamı & df & Karcler Ort. & F & P \\
\hline Gruplararasa &, 777 & 2 &, 389 &, 507 &, 605 \\
Grupiçi & 42,145 & 55 &, 766 & & \\
Toplam & 42,922 & 57 & & & \\
\hline
\end{tabular}

Tablo 14: Anova testi sonuçları

\begin{tabular}{|c|c|c|c|c|c|}
\hline & Bōlūmū & & $\bar{x}$ & Std & $\mathbf{p}$ \\
\hline \multirow{6}{*}{$\begin{array}{l}\text { Tukey } \\
\text { HSD }\end{array}$} & Sag̃lik Y.O & Salihli M.Y.O & ,05824 &, 32860 & 983 \\
\hline & & L.t.B.F & ,26599 &, 31312 & 674 \\
\hline & Salihli M.Y.O & Saglık Y.O &, 05824 &, 32860 &, 983 \\
\hline & & t.t.B.F &, 20775 &, 25825 &, 702 \\
\hline & t.1.B.F & Sağlık Y.O &,- 26599 &, 31312 & 674 \\
\hline & & Salihli M.Y.O &,- 20775 &, 25825 &, 702 \\
\hline \multirow{6}{*}{ LSD } & Saģlik Y.O & Salihli M.Y.O &, 05824 & 32860 & 860 \\
\hline & & t.t.B.F &, 26599 &, 31312 & ,399 \\
\hline & Salihli M.Y,O & Sağlık Y.O &,- 05824 &, 32860 &, 860 \\
\hline & & L.t.B.F &, 20775 &, 25825 &, 425 \\
\hline & I.L.B.F & Saglik Y.O &,- 26599 &, 31312 & ,399 \\
\hline & & Salihli M.Y.O &,- 20775 & .25825 &, 425 \\
\hline
\end{tabular}

Tablo 15: Post Hoc testleri

Tablo 14 incelendiğinde, halk dansları dersi seçen öğrencilerin öğrenim gördükleri bölümler açısından dans özyeterlik algılarında anlamlı bir farklılık olmadığı belirlenmiştir $F=, 507$ ve $p=, 605 p>, 01$. Ayrıca Post Hoc testleri sonuçlarına göre, (LSD ve Tukey) grupların kendi iç ortalamaları incelendiğinde $p>0,05$ olduğu tespit edilmiştir. Bu duruma göre, gruplar arasında puan ortalamaları bakımından dans özyeterlik algıları arasında anlamlı bir fark yoktur denilebilir.

Aşağıdaki tabloda, araştırmaya katılan "halk 
dansları dersi seçen öğrencilerin dans özyeterlik algıları ölçeği”nden aldıkları puanların ortalamaları bakımından cinsiyete göre İlişkisiz örneklem T-Testi sonuçları aşağıda (tablo 16) sunulmuştur.

\begin{tabular}{lllllll}
\hline Cinsiyet & $\mathbf{n}$ & $\bar{x}$ & sst & t & \multicolumn{2}{c}{ p } \\
\hline Kadun & 42 & 3,54 &, 92 & & \multirow{2}{*}{, 124} & \\
Erkek & 16 & 3,57 &, 72 & & & \\
\hline
\end{tabular}

Tablo 16: Cinsiyete göre Independent semplesT-testi sonuçları

Öğrencilerin, cinsiyet değişkeni bakımından dans özyeterlik algı değerleri incelendiğinde, (tablo 8) ölçeğe verdikleri puan ortalamaları $(\bar{x}=3,54$ / 3,57$)$ bakımından cinsiyetler arası anlamlı bir farklılığın olmadığı belirlenmiştir $(\mathbf{t}=, 124 ; p>0,05)$.

\section{Tartışma ve Sonuç}

Bu çalışmada, üniversitelerin farklı bölümlerinde öğrenim gören ve halk dansları dersi seçen öğrencilerin dans özyeterlik algı düzeylerini belirlemek amacıyla bir ölçme aracı geliştirilmiştir. 58 öğrenciye uygulanan 27 maddelik taslak ölçekten 16 maddelik nihai bir ölçek oluşturulmuştur. Ölçekte yer alan 14'ü olumlu, 2'si olumsuz ve ters puanlanması gereken sorulardır.

Ölçekte kalan 16 maddeye uygulanan faktör analizi sonucunda elde edilen KMO değeri .892 ve Bartlett küresellik testi anlamlılık değeri ise .00 'dır. Ölçekteki maddelerin tek boyutta toplandığı görülmüş ve tek faktörlü bir ölçme aracı elde edilmiştir. Bu tek faktör ölçeğe ait toplam varyansın \% 56,923'lük kısmını açıklamaktadır.

Maddelerin yük değerlerinin $(0,613-0,871)$ ve açıkladığı varyansın $(\% 56,923)$ yeni geliştirilen bir ölçüm aracı olmasına karşın çok yüksek olması, ölçeğin tek faktörlü yapısına güçlü kanıtlar oluşturmaktadır. Yapılan analizler ışığında elde edilen 16 maddelik tutum ölçeğine ait Cronbach Alpha değeri 948 olarak bulunmuştur. "Bu sonuç nihai ölçeğin yüksek bir güvenirliğe sahip olduğunu göstermektedir” (Tavşancıl, 2005: 29).

Çalışma kapsamında yapılan analizler sonucunda halk dansları dersi seçen öğrencilerin dans özyeterlik algılarını ölçebilecek ve kullanılabilir bir ölçüm aracı olduğu tespit edilmiştir. Yapılan geçerlik ve güvenirlik çalışması sonucu elde edilen bulgulara dayal, 16 madde ve tek faktörden oluştuğu ve üniversitelerin farklı bölümlerinde öğrenim gören öğrenciler üzerinde kullanılabileceğini, eğitimciler ve diğer araştırmacılar tarafından kullanılabilir bir ölçme aracı olduğu söylenebilir.

Çalışmaya katılan öğrencilerin cinsiyetleri bakımından dans özyeterlik algıları değerlendirildiğinde, her iki cinsiyet açısından dans özyeterlik algılarının yüksek düzeyde olduğu görülmektedir. Ölçeğe verdikleri puan ortalamalarına bakıldığında her iki cinsiyetin puan ortalamalarının birbirine oldukça yakın (kadın= 3,54; erkek= 3,57) olduğu ve aralarında fark olmadığı söylenebilir. Öğrenim gördükleri bölümler açısından grupların ölçeğe verdikleri puanların değerlendirme sonuçlarına göre, gruplar arasında anlamlı bir farkın olmadığını ( $p=, 605 ; p>0,05)$ göstermektedir.

Tokinan ve Bilen (2010), yaratıcı dans etkinliklerinin müzik öğretmeni adaylarının Oyun, Dans ve Müzik dersine ilişkin motivasyonları, özgüvenleri, beden dili ve dansa ilişkin özyeterlikleri ve dans performansları üzerinde anlamlı düzeyde etkili olduğu sonucuna ulaşmışlardır. Alp (2010), çalışmasında "Halk dansları icra eden dansçılar da ritim eşliğinde oynarken hem ritim duygularını geliştirip vücutlarını daha iyi kullanmayı öğrenecek hem de kasların hareketi sağlanacaktır" şeklinde yorumda bulunmuştur. Dansçının bedeninde çeşitli sesler, çeşitli etkiler yaratır. Sesin algılanması ve ona göre bir tepkinin verilmesi kişinin kültürüne, algılama gücüne, ritimleri ya da sesleri duyumsama yeteneğine, hangi ülkelerde yaşadığına, hatta onun görsel ve işitsel tercilerine bağlıdır. Bu gibi nitelikler, dansçının hareketlerini ve yorumunu etkilemektedir (Deleon, 1997: 556).

Quin, Redding ve Frazer (2007), farklı yaş grubuyla yaptıkları çalışmasında "çocuk yaşlarda müzikli hareket eğitimine katılımın ileri yaşlardaki dans edebilme becerileri parametrelerini etkilediği görülmektedir" sonucuna varmışlardır. Özelleşmiş ritmik hareket kalıpları, dans sanatında sıklıkla görülmektedir. Temel hareket ve özelleşmiş hareket kalıpları kazanan bir bireyin yaşamının farklı zamanlarında farklı tür bedensel aktivitelere yönelebileceği varsayılabilir. Bu bağlamda; ritim ve müzikle birlikte edinilen temel hareket eğitimi bireyi farklı türlerde ve farklı müziklerde dans etkinliklerine yönlendirebilir. 
Ancak, yetişkinler arasında dans etkinliklerine katılım azlığı ve katılımcıların öğrenme güçlüğü çektiğinin gözlenmesi, bu eğitimi çocuk yaşlarda veya gelişim dönemlerinde ya da üniversite yıllarında almadıkları görüşünü güçlendirmektedir (Turan ve Diğerleri, 2013).

Aldemir (2010), çalışmasında, "ritim, tekrar, sıralama, tahmin edebilme, öngörü, müzikal ipuçları, işitsel ayrı ve sayım gibi temel kavramların öğretildiği geleneksel dansların birçok eğitimsel hedefleri karşıladığı ve fiziksel yetenekleri ve koordinasyonu geliştirdiği bildirilmiştir" diyerek, halk dansları çalışmalarının bilişsel ve devinişsel birçok alanda yararlarından bahsetmiştir. Buradaki temel öncelik, "bedensel hareketin, iç duygu durumunu yansıtması ve hareket davranışındaki değişimlerin, ruhsal değişimlere yol açması, böylece sağlığın yükselmesidir" (Rainbow, 2005). Özevin (2006), “açıkça görülmektedir ki, Oyun- Dans ve Müzik dersinde ön plana çıkarılan kendini ifade etme yetisinin, yaratıcılığın ve estetik duyguların geliştirilmesinin, bu derse karşı motivasyonun artırılmasıyla yakındanilişkisi vardırvebu konuda yapılacak araştırmalara gereksinim duyulmaktadır" sözleriyle dans derslerine karşı öğrencilerin motivasyonlarının yüksek olmasının, bireylerin sosyal ve duygusal gelişimlerine etkisini ortaya koymaktadır.

Yukarıdaki araştırma bulguları elde ettiğimiz sonuçları desteklemektedir. Çünkü bireylerin çevreleri ile duygusal ve bilişsel bir bağlantı kurmalarını sağlayan sanatsal bir uygulamaya dâhil olmalarının, hem psikolojik hem de fiziksel iyileşmelere yardımcı olduğu araştırmamız bulguları arasında yer almaktadır. Araştırmanın bulguları doğrultusunda; Fakülte, Yüksekokul ve Meslek Yüksekokullarının farklı bölümlerinde öğrenim gören 58 öğrencinin katılımıyla gerçekleşen bu çalışma sonucunda; öğrencilerin halk dansları derslerine katılımları sonrasında, farklı türlerde dans çalışmalarına katılmaya istekli olmaları, dans ederken kendilerinde özgürlük hissi duymaları, dans edebilme konusunda kendilerine olan inançlarının pozitif yönde olduğu söylenebilir.

\section{Öneriler}

* Araştırma grubunu üniversite öğrencileri oluşturduğu için bundan sonraki yapılacak çalışmalarda, öğrenci olmayan ve farklı meslek gruplarından bireyler üzerinde çalışmanın ölçeğin geçerliği ve güvenirliğine katkı sağlayacağı düşünülmektedir.

* Farklı gruplar üzerinde yapılacak ölçümlerin sonuçlarına göre, dansa karşı özyeterlik duygularının düşük olduğu belirlenen öğrenciler için yeni öğretim yöntem ve stratejileri belirlenerek başlangıç seviyesinde ritim, müzik ve temel hareket eğitimi verilebilir.

* Kişilerin değer yargılarını şekillendiren inançları göz önünde bulundurularak basit adımlardan oluşan, halk dansları eğitimi verilerek bireylerin, genel anlamda dansa karşı özyeterliklerini olumlu yönde iyileştirmeye yönelik çalışmalar yapılabilir.

* Üniversitelerde halk dansları alanlarında öğrencilerin aktif katılımlarını sağlayabilecek olanakların sağlanması, öğrencilerin; bedenlerini kullanabilme, iletişim kurma becerileri geliştirebilme ve özgüvenleri açısından, üniversite eğitimin önemli bir parçası olacağı düşünülebilir.

\section{EK: Dans Özyeterlik ölçeği}

\begin{tabular}{|c|c|c|}
\hline $\begin{array}{l}\text { Tatlak } \\
\text { madde No }\end{array}$ & $\begin{array}{l}\text { Nihai } \\
\text { Madde No }\end{array}$ & Ölsek Sorulan \\
\hline s1 & 1 & Marrikle hareket etmektes hoglanirnm \\
\hline$\$ 2$ & 2 & Bedenimi kullanmada becerikliyim \\
\hline s6 & 3 & Duydugum ritme uygun hareket edebilirim \\
\hline 57 & 4 & Dans çalışmalarına katilnaya kstekliyim \\
\hline s16 & 3 & 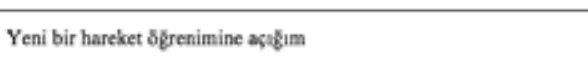 \\
\hline $\mathbf{s 2 0}$ & 6 & Märik kulagim iyidir \\
\hline 522 & 7 & Calınan ritmi anlayabilirim \\
\hline 525 & 8 & Dans ederken kendimi ōzgūr hissederim \\
\hline$\$ 31^{*}$ & 9 & Dans ederken utanyorum \\
\hline $\mathbf{s 3 3}$ & 10 & Grup içinde dans etmekten keyif alınm \\
\hline 836 & 11 & $\begin{array}{l}\text { Bir dansç gibi dans edemesem bile iyi dans edebilecegimi } \\
\text { düsûnūyorum }\end{array}$ \\
\hline$\$ 37^{*}$ & 12 & Dans konusunda iyi degilim \\
\hline 838 & 13 & Yeni danslar oğrenmekten mutlu olurum \\
\hline 340 & 14 & Arkadaşlanm dans etmemi bejenir \\
\hline 843 & 15 & Dans derslerinde kendimle gurur duyanm \\
\hline$s 44$ & 16 & Beden dilimi iyi kulhanyorum \\
\hline
\end{tabular}

* Ters maddeler 


\section{Notlar}

1- Bunlardan bazıları için bkz.: (Çevik, 2011), (Özmenteş, 2011), (Ekici, 2012,) (Öncü, 2012), (Yılmaz vd., 2007), (Güvenç, 2010), (Eker vd., 2013), (Yıldırım ve İlhan, 2010), (Çubukçu ve Girmen, 2007), (Aşkar ve Umay, 2001), (Gençtürk ve Memiş, 2010), (İnandı vd., 2013), (Kurbanoğlu ve Akkonyunlu, 2002), (Akar, 2008), (Bozdoğan ve Öztürk, 2008).

\section{Kaynakça}

Akar, Cüneyt (2008). "Öz-Yeterlik İnancı Ve İlkokuma Yazmaya Etkisi”. Uşak Üniversitesi Sosyal Bilimler Dergisi 1 (2): 185"198.Aktaş, Gürbüz. Temel Dans Eğitimi. İzmir: Ege Üniversitesi Baskı Evi, 1999.

Aldemir, G. Yasemin (2010). “Drama ve Dans Eğitiminin 10-14 Yaş Çocuklarda Motor Özelliklerin Gelişimine Etkisinin İncelenmesi”. Yüksek Lisans Tezi. İstanbul: Marmara üniversitesi.

Alp, M.Z., (2010). “Halk Oyunlarının Ritim Duygusu, Vücut Kompozisyonu Ve Reaksiyon Zamanının Gelişimi Üzerine Etkisi”, Yüksek Lisans Tezi, Sakarya Üniversitesi Sosyal Bilimler Enstitüsü, Sakarya.

Alpar, Reha (2006). Spor Bilimlerinde Uygulamalı İstatistik. Ankara: Nobel Yayıncılık.

Aşkar, Petek. Umay, Aysun (2001). “İlköğretim Matematik Öğretmenliği Öğrencilerinin Bilgisayarla ilgili Öz-Yeterlik Algısı". Hacettepe Üniversitesi Eğitim Fakültesi Dergisi (21): 1-8.

Acuner, Ahmet (2012). “Farklı Dansları Yapan Bireylerin Çeşitli Değişkenlere Göre Özgüven Ve Öz-Yeterliklerinin Karşılaştırılması". Yüksek lisans Tezi. Trabzon: Karadeniz Teknik Üniversitesi.

Board of Studies (2003). Dance Years 7-10 Syllabus. Board of Studies, Australia: Sydney.

Baykurt, Şerif (1995). Anadolu Kültürleri ve Türk Halk Dansları. Ankara: Yeni Doğuş Matbaası.

Barın, Nasuh (1999). Batı Dans Tarihi. Ankara: Kültür Bakanlığı Yayınları Sanat Eserleri Dizisi 247.

Bloom S. Benjamin (2012). İnsan Nitelikleri ve Okulda Öğrenme. çev: Durmuş Ali Özçelik. Ankara: Pegem Akademi 2. Baskı.

Bozdoğan, A. Emre. Öztürk, Çağrı (2008). “Coğrafya İle İlişkili Fen Konularının Öğretimine Yönelik Öz-Yeterlilik İnanç Ölçeğinin Geliştirilmesi”. Necatibey Eğitim Fakültesi Elektronik Fen ve Matematik Eğitimi Dergisi (2/2): 66-81.
Bozkurt, T. Kanbertay (2010). “İlköğretim Öğrencilerine Halk Dansları Öğretiminde Yaratıcı Drama Yöntemi Kullanılmasının Değerlendirilmesi”. Yüksek Lisans Tezi. Ankara: Ankara üniversitesi.

Büyüköztürk, Şener (2010). Veri Analizi El Kitabı. Ankara: Pegem Akademi 11. Basım.

Cüceloğlu, Doğan (2010). İnsan ve Davranışı. İstanbul: Remzi Kitapevi 19. Basım.

Çevik, D. Beste (2011). "Sınıf Öğretmeni Adaylarının Müzik Öğretimi Özyeterlik Düzeylerinin İncelenmesi”. Ahi Evran Üniversitesi Eğitim Fakültesi Dergisi (12/1): 145-168.

Çubukçu, Zühal. Girmen, Pınar (2007). “Öğretmen Adaylarının Sosyal Öz-Yeterlik Algılarının Belirlenmesi”. Eskişehir Osmangazi Üniversitesi Sosyal Bilimler Dergisi 8 (1): 57-74.

Daşdan, Gökay (2013). "Fiziksel Benlik Algısının Beden Dili ve Dansa Karşı Öz-Yeterlik Algısı Üzerine Etkisi”. Yüksek Lisans Tezi, Mersin: Mersin Üniversitesi.

Deleon, J., (1997). “200 Bale ve Dans”. Yapı Kredi Kültür Yayınları (38): 556-557.

Demirel. Mesut (2012). “Beden Eğitimi Öğretmenlerinin Halk Danslarına Yönelik Tutumları”. Yüksek Lisans Tezi. Kırıkkale: Kırıkkale Üniversitesi.

Eker, Fatma. Akkuş, Dilek. Kapısız, Özge (2013). “Ergenler İçin Madde Bağımlılığından Korunma Öz-Yeterlik Ölçeğinin Geliştirilmesi Ve Psikometrik Değerlendirilmesi”. Psikiyatri Hemşireliği Dergisi 4 (1): 7-12.

Ekici, Gülay (2012). “ Akademik Öz-Yeterlik Ölçeği: Türkçeye Uyarlama, Geçerlik Ve Güvenirlik Çalışması”. Hacettepe Üniversitesi Eğitim Fakültesi Dergisi (43): 174-185.

Ekici, Metin (2007). Halk Bilgisi (Folklor) Derleme ve İnceleme Yöntemleri. Ankara: Geleneksel Yayınları:7. 2. Baskı.

Erdoğan, İrfan (2007). Pozitivist Metodoloji. Ankara: Erk Yayınları.

Eroğlu, Türker (1995). Halk Oyunları Ve Halayların İncelenmesi. Ankara: Kılıçaslan Matbaası.

Fidan, Nurettin (2012). Okulda Öğrenme ve Öğretme. Ankara: Pegem Akademi 3. Baskı.

Gençtürk, Aycan. Memiş, Aysel (2010). “İlköğretim Okulu Öğretmenlerinin Öz-Yeterlik Algıları ve İş Doyumlarının Demografik Faktörler Açısından İncelenmesi”, Eğitim Online 9(3): 1037-1054. 
Güvenç, Hülya (2010). “Ders Çalışma Özyeterlik Algısı Ölçeğinin Geliştirme Çalışması”. Yüzüncü Yıl Üniversitesi Eğitim Fakültesi Dergisi 7(1) :59-69.

İkiz, F. Ebru. Yörük, Canan (2013). “Öğretmen Adaylarının Öz-Yeterlik Düzeyleri ile Aile İşlevlerinin İncelenmesi”. Uşak Üniversitesi Sosyal bilimler dergisi 6 (1) :228-248.

İnandı, Yusuf. Tunç, Binali. Gündüz, Bülent (2013). "Okul Yöneticilerinin Özyeterlik Algıları ile Çatışmayı Çözme Stratejileri Arasındaki İlişki”. Kuram ve Uygulamada Ĕ̆itim Yönetimi Dergisi 19(2) :275-294.

İnceoğlu, Metin (2010). Tutum Algı İletişim. İstanbul: Beykent Üniversitesi Yayınları No: 69, 5. Baskı.Kağıtçıbaşı, Çiğdem (2010). Günümüzde İnsan ve İnsanlar - Sosyal Psikolojiye Giriş. İstanbul: Evrim Yayınevi.

Karasar, Niyazi (2008). Bilimsel Araştırma Yöntemi. Ankara: Nobel Yayıncılık.

Kassing G. Jay D M. (2003). Dance Teaching Methods and Curriculum Design. Northern Illinois University. Human Kinetics.

Koçkar, Tekin (1990). Dansın İletişimsel İşlevi, Kurgu Dergisi Sayı:8, Syf:328.

Kurtişoğlu, Bülent; Altuğ, S. Tansu (2009). “Kırkpınar Güreşlerinde Çalınan Güreş Müziklerinin Melodik ve Ritmik Yönden İncelenmesi ve Uygulamalı Açıklaması”. V. Tarihi Kırkpınar Sempozyumu Bildirisi, s: 64-70.

Kurbanoğlu, Serap; Akkoyunlu, Buket (2002). “Öğretmen Adaylarına Uygulanan Bilgi Okuryazarlığı Programının Etkililiği Ve Bilgi Okuryazarlığı Becerileri İle Bilgisayar ÖzYeterlik Algısı Arasındaki İlişki”. Hacettepe Üniversitesi Eğitim Fakültesi Dergisi (22): 98-105.

Madran, A. Demirtaş (2012). Tutum, Tutum Değişimi ve İkna. Ankara: Nobel Akademik Yayıncılık.

McCutchen, B.P. (2006). Teaching Dance As Art in Education, Human Kinetics.

McGreevy. S., Scheff H., Sprague M. (2005). Building Dances. Second Edition, Human Kinetics.

Öncü, Hüseyin (2012). “Akademik Özyeterlik Ölçeğinin Türkçe’ye Uyarlanması”. Ahi Evran Üniversitesi Kırşehir Eğitim Fakültesi Dergisi 13(1): 183-206.

Örnek, S. Veyis (1973). Budunbilim Terimleri Sözlüğü. Ankara: Türk Dil Kurumu Yayınları.
Özevin, B. (2006), “Oyun Dans Ve Müzik Dersine İlişkin Motivasyon Ölçeği”, Ulusal Müzik Eğitimi Sempozyumu Bildirisi, Denizli.

Özdemir, Banu (2007). “Üniversite Öğrencilerinde Görülen Depresyonun Giderilmesinde Dansın Etkisi”. Yüksek Lisans Tezi. Konya: Selçuk Üniversitesi.

Özgen, Kemal. Bindak, Recep (2011). “Lise Öğrencilerinin Matematik Okuryazarlığına Yönelik Öz-Yeterlik İnançlarının Belirlenmesi” Kuram ve Uygulamada Eğitim Bilimleri Dergisi 11(2): 1073-1089.

Öztürk, Mutlu (1990). "Halk Oyunlarında Kriz Ve Büfk Dans Birimi: Krizden Çıkış İçin Notlar”, Folklora Doğru Dans Müzik Kültür Araştırmaları Dergisi (59) :65-80.

Özmenteş, Sabahat (2011). “Müzik Öğretimine Yönelik Özyeterlik Ölçeğinin Geliştirilmesi”. Eğitimde Yeni Trendler ve Bunların Yan Etkileri Konferansı Bildiri Kitapçı̆̆ı, s: 159-165.

Özyürek, Mehmet (2013). Engellilere Yönelik Tutamların Değiştirilmesi. Ankara: Kök Yayıncılık 4. Basım.

Purcell T.M. (1994). Teaching Children Dance. New Jersey, Kendall Park: Human Kinetics.

Edel, Quin. Lucy, Frazer. Emma, Redding. (2007). “The Health Benefits Of Creative Dance: İmproving Children's Physical And Psychological Wellbeing", Education and Health (25)2: 31-33.

Rainbow, T.H., (2005), "Effects Of Dance Movement Therapy On Chinese Cancer Patients: A Pilot Study in Hong Kong”, Arts in Psychotherapy (32)5: 337-345.

Senemoğlu, Nuray (2009). Gelişim Öğrenme ve Öğretim. Ankara: Pegem Yayıncılık 15. Baskı.

Şahin, Bahar. Gülleroğlu H. Deniz (2013). “Likert Tipi Ölçeklere Madde Seçmede Kullanılan Farklı Madde Analizi Teknikleri İle Oluşturulan Ölçeklerin Psikometrik Özelliklerinin İncelenmesi”, Asya Öğretim Dergisi 1(2): 1828.

Tavşancıl, Ezel (2014). Tutumların Ölçülmesi ve SPSS ile Veri Analizi. Ankara: Nobel Akademik Yayıncılık 5. Basım.

Tokinan, B. Özevin (2008). "Yaratıc dans etkinliklerinin motivasyon, özgüven, özyeterlik ve dans performansı üzerindeki etkileri”. Doktora Tezi, İzmir: Dokuz Eylül Üniversitesi. 
Tokinan, B. Özevin. Bilen, Semih (2010). "Beden Dili Ve Dansa İlişkin Özyeterlik Değerlendirme Formu Geliştirme Çalışması", Ankara Üniversitesi Eğitim Bilimleri Fakültesi Dergisi 43(2) : 75-88.

Turan, Zeynel (2001). “Türk Halk Oyunları Türlerinden Halayların Yapısal Özellikleri”. Yayınlanmamış Yüksek Lisans Tezi. İzmir: Ege Üniversitesi.

Turan, Zeynel. Köse, Fisun. Çamlıyer, Hatice. (2013). “İlköğretim Birinci Devre Çocuklarının Temel Hareket Becerilerinin Geliştirilmesinde Ritim Ve Müzik Eğitiminin İlişkisi”. 8. Ulusal Beden Eğitimi ve Spor Öğretmenliği Kongresi Bildirisi. Mersin.

Turanlı N, Türker NK, Keçeli V. (2008). “Matematik Alan Derslerine Yönelik Tutum Ölçeği Geliştirilmesi”. Hacettepe Üniversitesi Eğitim Fakültesi Dergisi (34): 254-262.

Usta, İlker (2008). “Öğrenme Stillerine Göre Düzenlenen Beyin Temelli Öğrenme Uygulaması”. Yüksek lisans tezi. Isparta: Süleyman Demirel Üniversitesi,

Ülgen, Gülten (1995). Eğitim Psikolojisi - Birey ve Öğrenme. Ankara: Bilim Yayınları.

Yanık, Esin (2010). “Dans ve İletişim”. Yüksek Lisans Tezi. Sakarya: Sakarya üniversitesi.

Yıldırım, Fatma. İlhan, İ. Özgür (2010). “Genel Özyeterlik Ölçeği Türkçe Formunun Geçerlilik Ve Güvenilirlik Çalışması”. Türk Psikiyatri Dergisi 21(4): 301-8.

Yılmaz, Miraç. Gürçay, Deniz. Ekici, Gülay (2007). “Akademik Özyeterlik Ölçeğinin Türkçe'ye Uyarlanması”. Hacettepe Üniversitesi Eğitim Fakültesi Dergisi (33) :253-259.

Yoncalık, Oğuzhan (2004). "Millî Eğitimde Bir Kültür Aktarım Alanı Olarak Halk Oyunları (Dansları) Ve Beden Eğitimi Öğretmenliği”. Millî Eğitim Eğitim-Kültür-Sanat Dergisi (164).

Yoncalık, Oğuzhan (2007). “Kültür ve Spor Bağlamında Cinsiyetin “Dans”a Yönelik Tutuma Etkisi”. Milli Eğitim Dergisi (176): 109-117. 